Іваницький М. Г., канд. військ. наук, доцент ${ }^{1}$

(0000-0001-5137-6591); Саганюк Ф. В., канд. юрид. наук, доцент ${ }^{2}$

Мудрак Ю. М. ${ }^{2}$ (0000-0002-9516-0562);

Пальчик А. B. ${ }^{2}$

1 - Кафедра керівництва військами (силами) в мирний час Національного університету оборони України імені Івана Черняховського, Київ;

2 - Центр воєнно-стратегічних досліджень Національного університету оборони України імені Івана Черняховського, Київ.

\title{
Підходи до аналізу чинників, які впливають на розвиток Збройних Сил України та інших складових сил оборони
}

Резюме. Розглянуто підходи до аналізу чинників, які впливають на розвиток Збройних Сил України та інших сил оборони для визначення шляхів його вдосконалення та наближення до принципів і стандартів HATO.

Ключові слова: Збройні Сили України; оборонний огляд; стратегічне і оборонне планування; спроможності сил оборони; стратегічні цілі; чинники.

Постановка проблеми. У сучасних умовах підвищення бойових спроможностей Збройних Сил України та інших складових сил оборони для активної протидії агресору набуває все більшої актуальності.

Важливою процедурою у процесі стратегічного i оборонного планування розвитку спроможностей Збройних Сил (3С) України та інших складових сил оборони (СО) $\epsilon$ аналіз та врахування впливу зовнішніх i внутрішніх чинників.

Аналіз останніх досліджень i публікацій. У [1] визначають чинники $я к$ умови та рушійні сили, що впливають на об'єктивність планування заходів та ефективність їх реалізації на практиці.

Зовнішніми чинниками у [2] називають умови, які об'єктивно виникають у зовнішньому середовищі. Їх аналіз дає змогу виявляти сприятливі сторони, які можуть використовуватися для досягнення визначених стратегічних цілей, а також негативні, які можуть становити певні загрози та небезпеку або обмежувати розвиток 3С та інших складових СО.

До внутрішніх чинників у $[3,4]$ відносять економічні, технологічні, політичні та соціальні явища, а також організаційну структуру, гнучкість системи управління; організацію та принципи діяльності управлінців у цій системі; якість та швидкість одержання інформації, що стосується їх діяльності; створення відповідної мотивації для персоналу, зайнятого у цій сфері тощо. Однак як саме враховувати їх під час стратегічного i оборонного планування розвитку спроможностей $3 \mathrm{C}$ та $\mathrm{CO}$ у цих публікаціях не досліджено.

Метою статті $є$ дослідження наявних підходів до аналізу чинників, які впливають на розвиток ЗС та інших складових $\mathrm{CO}$ для визначення ефективних шляхів цього розвитку і активнішої протидії агресору.

Виклад основного матеріалу. Під чинниками розуміють умови, рушійні сили, причини будь-якого процесу, що визначають його характер або одну з основних рис [1-4]. Деякі чинники, які можуть впливати на формування та розвиток спроможності військ (сил) наведені у Воєнній доктрині України. Тут вони названі “тенденціями". Серед них визначені такі:

посилення суперечностей щодо поділу сфер впливу між світовими центрами сили, збільшення їх агресивності, непоступливості, прагнення порушити на свою користь воєнностратегічну рівновагу, зокрема, загострення протистояння між США та Російською Федерацією;

послаблення ролі міжнародних безпекових інститутів, спроби посилити роль воєнної сили поза наявними механізмами міжнародної безпеки;

перенесення ваги у воєнних конфліктах на асиметричне застосування воєнної сили не передбаченими законом збройними формуваннями, зміщення акцентів у воєнних конфліктах на використання не лише воєнних, a i невоєнних інструментів (економічних, політичних, інформаційно-психологічних тощо), що принципово змінюе характер збройної боротьби; 
порушення норм i принципів міжнародного права;

розширення масштабів тероризму, піратства, інших явищ, пов'язаних із застосуванням збройного насильства;

поширення практики проведення спеціальних операцій та дій провокаційного характеру для створення конфліктних ситуацій;

посилення внутрішньої нестабільності, намаганнями етнічних утворень сепаратно вирішувати нагальні проблеми;

посилення мілітаризації, активна дестабілізуюча зовнішня політика 3 боку Російської Федерації щодо сусідніх держав, а також щодо міжнародних організацій, включаючи НАТО та ЄС;

відмова або ухилення Російської Федерації від виконання зобов'язань за міжнародними договорами;

інформаційна війна Російської Федерації проти України тощо.

Зазначені чинники не втратили свого загрозливого впливу у сферах безпеки i оборонній донині. Однак під час стратегічного i оборонного планування їх потрібно уточнювати для визначення відповідних сценаріїв планування військ (сил) та необхідних їм ресурсів і спроможностей.
Спроможності сил

оборони, як визначено у чинній Воєнній доктрині України - це здатність досягати необхідного результату під час виконання завдань 3 питань оборони саме у певних умовах та відповідно до визначених сценаріїв дій 3 використанням наявних ресурсів.

Представляється, що саме ці умови та сценарії дій підлягають визначенню як під час оборонного огляду 3С та інших складових СО, так і під час планування застосування військ (сил) та ресурсів [5], що потребує більш грунтовного наукового дослідження. Зокрема, у [1] процедуру 3 аналізу чинників, що впливають на досягнення стратегічної цілі, визначають як одну 3 ключових. Основним іiі завданням вважають виявлення сильних i слабких сторін чинників. Сильні сторони - це особливі властивості або якість чинників, які відділяють їх від інших ознак. Слабкі сторони - це якості, яких не вистачає для виконання визначених завдань та досягнення певної стратегічної цілі.

Для цього виділяють компоненти чинників, здійснюють відповідну класифікацію 3 погляду позитивного (+) та негативного (-) впливу для планування відповідних заходів щодо їх врахування, як наведено у табл. 1.

Таблиця 1

Варіант планування заходів для врахування результатів аналізу сильних і слабких сторін чинників

\begin{tabular}{|c|c|c|c|}
\hline $\begin{array}{l}\text { Сильні } \\
\text { сторони }\end{array}$ & $\begin{array}{l}\text { Слабкі } \\
\text { сторони }\end{array}$ & $\begin{array}{l}\text { Характеристика } \\
\text { Чинника }\end{array}$ & $\begin{array}{c}\text { Заходи, щодо зміцнення сильних i } \\
\text { послаблення впливу слабких сторін чинників }\end{array}$ \\
\hline \multicolumn{4}{|c|}{ Доктринальні (концептуальні) складові спроможностей } \\
\hline \multirow[t]{2}{*}{+} & \multirow[b]{2}{*}{-} & $\begin{array}{l}\text { Визначений КМ України “Порядок } \\
\text { проведення оборонного огляду МО" } \\
\text { (OO) }\end{array}$ & $\begin{array}{l}\text { Довести для використання в роботі та під час } \\
\text { здійснення визначених Порядком процедур }\end{array}$ \\
\hline & & $\begin{array}{l}\text { Недосконалість законодавчої та іншої } \\
\text { нормативно-правової бази сектору } \\
\text { безпеки і оборони } \\
\text { правове забезпечення) }\end{array}$ & $\begin{array}{l}\text { Розробити заходи щодо кодифікації } \\
\text { законодавства у сфері оборони для скорочення } \\
\text { надмірної його правової бази. } \\
\text { Удосконалити організаційну структуру сил } \\
\text { оборони для дій на Сході України, наблизивши } \\
\text { iї до організованих структур, визначених за } \\
\text { принципами і стандартами НАТО }\end{array}$ \\
\hline \multicolumn{4}{|c|}{ Командування та управління військами (силами) } \\
\hline & - & $\begin{array}{l}\text { Незадовільне кадрове забезпечення } \\
\text { військ (сил) особливо на південно- } \\
\text { східному напрямку України }\end{array}$ & $\begin{array}{l}\text { Поліпшити комплектування СО особовим } \\
\text { складом. } \\
\text { Завершити перехід насамперед на Сході } \\
\text { України, на комплектування військ (сил) за } \\
\text { контрактом } 3 \text { наближенням до прийнятих у } \\
\text { НАТО принципів кадрової політики. } \\
\text { Підвищити професійний рівень персоналу СО. } \\
\text { Створити достатній військовий резерв }\end{array}$ \\
\hline \multicolumn{4}{|c|}{ Іниі базові складові спроможності ЗС та СО } \\
\hline
\end{tabular}

Під час аналізу слабких сторін мають бути максимально об'єктивно оцінені та враховані чинники, що обмежують спроможність військ (сил) чи розвиток спроможності певних підрозділів. Це дасть змогу визначити зони підвищеної уваги, а також такі 3 них, на які можна спиратися у процесі планування розвитку військ (сил). Для цього процес аналізу впливу чинників на стратегічне планування розвитку військ (сил) та їх спроможностей здійснюється шляхом порівняльного SWOT-аналізу (S - strenght - 
сила, W - weakness - слабкість, О - opportunites - можливості, T - threats - загрози). Цей метод у літературі широко представлений, наприклад, $\mathrm{y}[6]$.

Аналіз чинників, які впливають або можуть впливати на розвиток 3С та інших складових СО дає змргу виявити певні їх закономірності та врахувати під час планування відповідних заходів. Заходи щодо розвитку спроможностей військ (сил) для певних умов рекомендується планувати на основі базових складових, передбачених системою DOTMLPFI, яка включає доктринальну базу, структурну організацію військ (сил), систему їх підготовки, ресурсне забезпечення та інші складові [7].

У [8] рекомендують класифікувати чинники так:

економічні, що відображають тенденції економічного розвитку України; соиіальні та

культурні,

що характеризують стан і тенденції освіченості персоналу, специфіку звичаїв і традицій та інших цінностей в аспекті їх впливу на діяльність військ (сил);

правові - відображають систему стосунків, врегульованих законодавством, зокрема вказують на яких умовах доцільно здійснювати ту чи іншу військову діяльність, які нормативно-правові акти $є$ у цій сфері діяльності тощо;

технологічні - аналізують 3 погляду їх впливу на зміст та методи діяльності військ (сил), чи $є$ можливість використання мережі Інтернет, інших засобів комунікації для реалізації визначених цілей тощо.

Аналіз впливу чинників, що можуть впливати на розвиток військ (сил), можна здійснити за допомогою табл. 2.

Таблиця 2

Варіант аналізу впливу чинників на розвиток спроможності військ (сил)

\begin{tabular}{|c|c|c|c|}
\hline Можливості & Загрози & $\begin{array}{l}\text { Чинники, що впливають на розвиток } \\
\text { спроможностей військ (сил) }\end{array}$ & $\begin{array}{c}\text { Що треба зробити для використання } \\
\text { можливості або протидії негативному } \\
\text { чиннику }\end{array}$ \\
\hline \multicolumn{4}{|c|}{ Агресія РФ проти Украӥни та ускладнення воснно-політичної обстановки } \\
\hline & - & $\begin{array}{l}\text { участь регулярних військ, радників, } \\
\text { інструкторів і найманців РФ у бойових } \\
\text { діях на території України; } \\
\text { розвідувально-підривна і диверсійна } \\
\text { діяльність і розпалювання ворожнечі та } \\
\text { ненависті, сепаратизму і тероризму; } \\
\text { анексія території АРК та дії щодо } \\
\text { дестабілізації обстановки на Донбасі; } \\
\text { нарощування військових угруповань } \\
\text { біля кордонів та на тимчасово окупованій } \\
\text { території України; } \\
\text { відсутність ефективних зовнішніх } \\
\text { гарантій безпеки України; } \\
\text { діяльність незаконних збройних } \\
\text { формувань }\end{array}$ & $\begin{array}{l}\text { привести систему оборони України } \\
\text { та стратегічного керівництва нею до } \\
\text { принципів і стандартів НАТО, а саме: } \\
\text { створити на півдні Сходу України } \\
\text { оперативно-стратегічне угруповання } \\
\text { військ (СО) під єдиним керівництвом } \\
\text { ООК, а також мобільних оперативн-- } \\
\text { тактичних угруповань у складі } \\
\text { армійських корпусів для забезпечення } \\
\text { формування оперативно-стратегічного } \\
\text { угруповання військ (сил) ЗС України та } \\
\text { інших складових СО }\end{array}$ \\
\hline \multicolumn{4}{|c|}{$\begin{array}{c}\text { Проведення РФ спецоперацій проти Украӥни (блокада портів, морського } \\
\text { чи повітряного просторів тощо (далі аналіз інших чинників) }\end{array}$} \\
\hline
\end{tabular}

Чинники, що створюють небезпеку життєво важливим національним інтересам України, вважаються загрозами національній безпеці. До них у [9] пропонують відносити:

окупацію Росією Криму та частини території Донецької і Луганської областей;

нарощування РФ військової потужності у межах цих територій i в безпосередній близькості до українських кордонів, зокрема носіїв тактичної ядерної зброї;

мілітаризацію РФ окупованих територій шляхом формування нових військових з'єднань i частин, a також постачання бойовиків, військової техніки та засобів матеріальнотехнічного забезпечення;

нарощування РФ біля державного кордону України угруповання військ 3 потужним ударно-наступальним потенціалом; створення нових, розширення та модернізація наявних баз, об'єктів військової інфраструктури;

активізацію спеціальними службами РФ розвідувально-підривної діяльності в Україні для дестабілізації внутрішньої соціальнополітичної обстановки в Україні, а також підтримання непередбачених законом збройних формувань на Сході України i створення умов для збільшення масштабів збройної агресіі;

нарощування агресивних дій 3 боку РФ проти України, зокрема морських операцій 3 агресивними воєнно-політичними цілями, інших спеціальних операцій із застосуванням військових підрозділів та/або частин, вогневих ударів, інформаційних, інформаційно- 
психологічних операцій (дій) із застосуванням невоєнних засобів;

блокади 3 боку РФ із застосуванням воєнної сили морських портів і акваторій, узбережжя та повітряного простору України, порушення іiі комунікацій тощо.

Ключовими завданнями створення умов для протидії негативним чинникам, зокрема для відновлення державного суверенітету i територіальної цілісності держави пропонується визначити:

комплексне реформування системи забезпечення національної безпеки до рівня, прийнятного для членства в СС і НАТО;

створення ефективного складу $3 \mathrm{C}$ та інших складових $\mathrm{CO}$, забезпечення достатніх необхідних їм спроможностей для ефективної відсічі збройній агресії;

створення структури $3 \mathrm{C}$ та інших складових $\mathrm{CO}$, яка відповідатиме західним стандартам, прийнятим у збройних силах держав-членів НАТО [9].

Аналіз цих та інших чинників, які впливають на розвиток ЗС та інших складових $\mathrm{CO} \epsilon$ важливою процедурою планування сил i ресурсів, формування відповідних заходів щодо забезпечення необхідних їм спроможностей для оборони України, захисту іiі суверенітету, територіальної цілісності та недоторканності.

Висновок. Аналіз чинників, які впливають або можуть впливати на розвиток ЗС та інших складових $\mathrm{CO}$ дає змогу виявити певні їх закономірності та врахувати під час планування відповідних заходів щодо розвитку ЗС та інших складових СО для забезпечення необхідних їм спроможностей i активної оборони держави від агресора.

Напрям подальших досліджень. Розроблення за результатами оборонного огляду необхідних варіантів проєктів нової Стратегії воєнної безпеки України та
Стратегічного оборонного бюлетеня України доцільно здійснювати 3 урахуванням аналізу наявних та потенційних чинників, що впливають на ефективність планування розвитку ЗС та інших складових $\mathrm{CO}$, наблизивши цей процес до принципів $\mathrm{i}$ стандартів, прийнятих в арміях державчленів НАТО.

\section{СПИСОК ВИКОРИСТАНОЇ ЛІТЕРАТУРИ}

1. Азарова Т. В., Абрамов Л. К. Стратегічне планування діяльності. Кіровоград: ЦПТІ, 2000. $92 \mathrm{c}$.

2. Чинники впливу на планування зовнішньоекономічної діяльності. Науковий вісник НЛТУ Украӥни. 2012. Вип. 22/8. С. 296301.

3. Дроздова Г. М. Менеджмент зовнішньоекономічної діяльності підприємства : навч. посібн. Київ, 2002. 172 с.

4. Маргасова В. Г., Роговий А. В., Виговська В. В. Аналіз фінансових результатів зовнішньоекономічної діяльності суб'єктів господарювання. Актуальні проблеми економіки : наук. економ. журнал. Київ, 2009. № 3 (93). C. 207-213.

5. Сектор безпеки i оборони України: теорія, стратегія, практика : монографія / Ф.В. Саганюк, В. С. Фролов, О.В. Устименко, М. М. Лобко та ін. Київ : Академпрес, 2017. 182c. URL: http:// www.nationalsecurity.in.ua/sector-of- security-anddefense-of-ukraine.

6. Методика проведення SWOT аналізу. URL: http://marketing.by/novosti-rynka/metodikaprovedeniya-swot-analiza-obraztsy-matrits-swot.

7. Біла книга - 2017. Збройні Сили України. Київ : МО України, 2018. С. 11.

8. Кузьмін О. Є., Мельник О. Г. Теоретичні та прикладні засади менеджменту. Львів, 2007. 384 c.

9. Воєнна доктрина України (Стратегія воєнної безпеки України) (проєкт). URL: http://www.mil. gov.ua/content/public_discussion/proj_vdu.pdf.

Стаття надійшла до редакційної колегії 03.10.2019

Іваницкий М. Г., канд. воен. наук, доцент ${ }^{1}$;

Саганюк Ф. В., канд. юрид. наук, доцент ${ }^{2}$;

Мудрак Ю. М. ${ }^{2}$;

Пальчик А. В. ${ }^{2}$

1 - Кафедра управления войськами (силами) в мирное время Национального университета обороны Украины имени Ивана Черняховского, Киев;

${ }^{2}$ - Центр военно-стратегических исследований Национального университета обороны Украины имени Ивана Черняховского, Киев

Подходы к анализу факторов, влияющих на развитие Вооруженных Сил Украины та иных сил обороны

Резюме. Рассмотрены подходы к анализу факторов, влияющих на развитие Вооруженных Сил Украины и других сил обороны для определения путей его совершенствония на основе принципов и стандартов НАТО. 
Ключевые слова: Вооруженные Силы Украины; оборонный осмотр; стратегическое планирование; возможности сил обороны; стратегические цели; факторы.

\section{Ivanitsky, PhD (Military), assistant professor ${ }^{1}$;}

F. Saganiuk, PhD (Yurydychnykh), assistant professor ${ }^{2}$;

Y. Mydrak ${ }^{2}$;

A. Palchik ${ }^{2}$

${ }^{1}$ - Department of guidance by troops (by forces) in the peace-time of the National Defence University of Ukraine named after Ivan Cherniakhovskyi, Kyiv;

${ }^{2}$ - Center for Military and Strategic Studies of the National Defence University of Ukraine named after Ivan Cherniakhovskyi, Kyiv

Going is near the analysis of factors which influence on development of Military Powers of Ukraine and other component forces of defensive

Resume. Going is considered near the analysis of factors which influence on development of Military Powers of Ukraine and other forces of defensive for determination of ways of his perfection and approaching to principles and standards of NATO.

Keywords. Armed Forces of Ukraine; defense review; strategic planning; the capabilities of the forces of defense; strategic goals; factors. 